\title{
OVERVIEW OF COMBINE HARVESTER AND TRACTOR STRUCTURE ON FARMS IN THE CZECH REPUBLIC
}

\author{
Jiri Masek, Petr Novak \\ Czech University of Life Sciences Prague, Czech Republic \\ masekj@tf.czu.cz,novakpetr@tf.czu.cz
}

\begin{abstract}
Agricultural machinery in general is the main means of realizing the production plan on the farm. There is a difference between big and small size farms in the structure of agricultural machine use. It depends on the utilization ratio and annual performance of the machines and also on the production structure. New machines are primarily acquired by economically strong subjects, which are able to create the right condition for intensive use and fast renewal rate of this new machinery. This study was made for tractors and selfpropelled combine harvesters in the Czech Republic conditions. There was big investment in this sector to the technology and machines in recent years. However, the results still show a long-term failure in the tempo of recovery and this can have a negative impact on the technical state of the machines and technological lines, their operation reliability, environmental aspects of production and operating costs of machines with negative resulting to production economics. The result shows that the rate of machine innovation depends not only on the economic prosperity and stability of agricultural companies, but strongly on capital support from public resources, too. In the paper the numbers of machinery in the agricultural sector in the last 20 years in the Czech Republic are evaluated. After renewal, the technique is reducing the number of machines expected due to higher efficiency and performance. Renewal of combine harvesters depends on 6 years cycle due to the depreciation period in accounting and the selling process of harvesting machines has a seasonal character.
\end{abstract}

Keywords: machine structure, tractor, market, combine harvester.

\section{Introduction}

Agricultural machinery is one of the key elements ensuring and realizing the business plan in agricultural plant production. Renewal of the machines presents considerable investment demands often and requires effort to be covered by high capital sources. Investment to the machinery has a long time payback period, and a bad decision could have negative impacts on the economic stability of the agricultural company. A lack of quality information and not well-established management of processes for decision-making often mark the renewal of agricultural machinery. Final decision is often make on intuitive base [1]. Level of technical equipment of agricultural machines on farms is not only the statement of economic prosperity of the agricultural sector, but also it is affected by technical policies of the sector [2]. Farmers need help to find an optimal level of farm mechanisation in terms of technical capability [3]. The present situation of agricultural machines and equipment is influenced by both, the total income of the agricultural companies and by the specific condition of the soil or the animal welfare. In the Czech Republic, the average number of tractors and selfpropelled machines per farm is low, when compared with the European Union [4]. One of the main reasons is the high concentration of production in large-scale farms enabling the distribution of the fixed costs [5]. There are significant differences in equipment and machine needs depending on the size of the farm [1].

The process of mechanization of Czech agriculture was in the decisive sectors practically completed in the seventies with the effective support of machine investments in the form of subsidies made by state. Agricultural technical policy was based on the direct allocation of machine limits and direct investment subsidies. In the 1980s, there was a certain downturn in subsidies for machinery investments, machine renewal stagnated, purchases of new machines did not ensure simple reproduction, and the gradual aging of the machinery flew [5]. The machines during that time came from the east part of Europe. Main tractors ware at that time Czech Zetor, followed by Belarus, Fortschritt and Ursus. Combine harvesters during socialistic time were Fortschritt (E 512, E 516, E 514), BIZON and DON 1500. The Velvet Revolution in 1989 started new era of agricultural machinery on the Czech market and new brands established their sales network.

This political change affected increasing of the intensity of the modernization process in the whole agriculture sector and the high-speed renewal dynamics of the agricultural machinery fleet [6]. According to the EU survey, more than $56 \%$ of farmers would like to invest in new machines and equipments between 2014 and 2020 [7]. 


\section{Materials and methods}

Data evaluated in the article are collected form open databases and public sources - Czech Statistical Office, Czech Central Register of Mobile Machines and Association of Importers of Agricultural Machinery. Numbers of specific machines, such as combine harvesters and forage choppers, are evaluated according to questionnaires answered by the dealers of machines. There are 16 seasons for evaluation with detailed view to the years 2011, 2014, 2015 and 2016. All data were processed by statistical analyses by ANOVA test in STATISTICA software on the chosen level of relevance $(\alpha=0.05)$.

\section{Results and discussion}

Situation in the central register is not corresponding to the current selling numbers of tractors. It is due to historical development of major using Zetor tractors. Lot of people in villages have their own old Zetor tractor at home for some hobby purposes - big garden, small-scale animal husbandry, etc. If we look at the selling numbers of new tractors, Zetor still has a dominant position on the market, but in lower power classes of tractors. In Fig. 1 and Fig 2. you can find total numbers of selling units of new tractors and combine harvesters during $2000-2016$ [8]. Year 2008 was significant due to the highest selling number of all machines. It is affected by the level of subsidies and commodity prices.

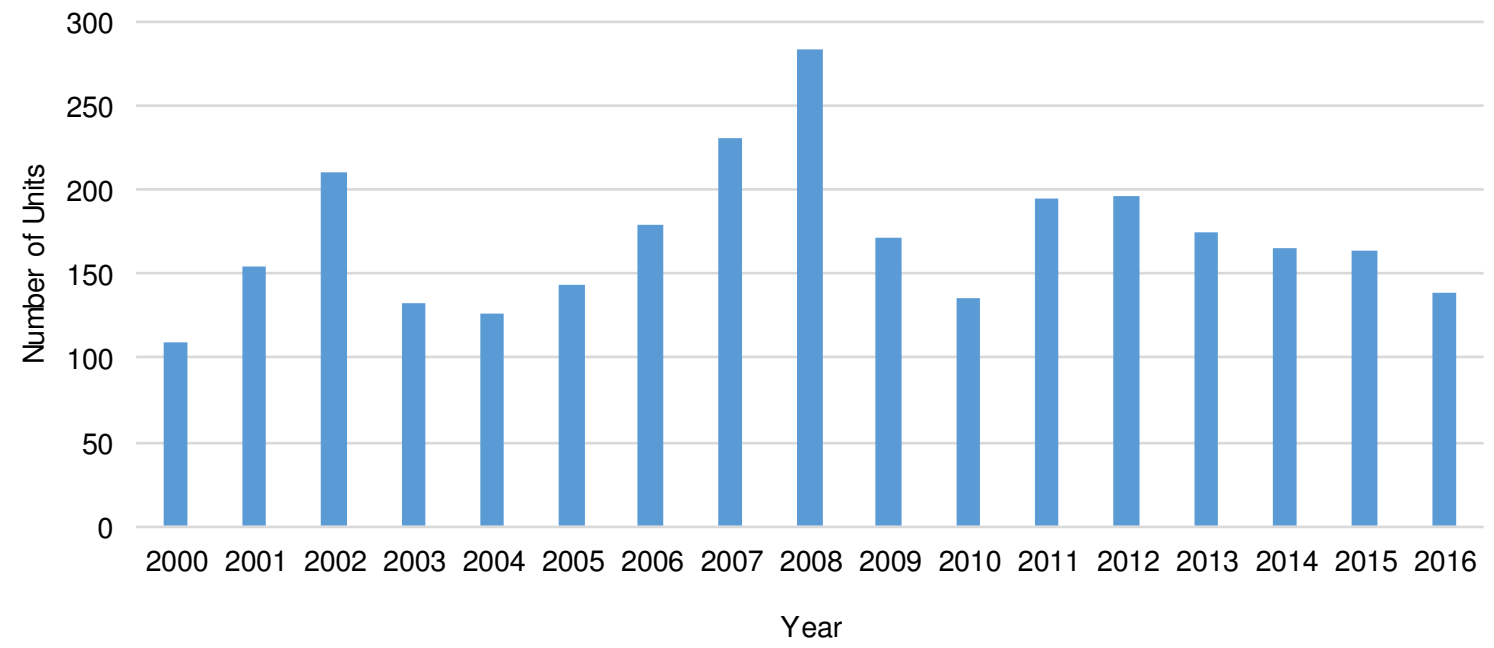

Fig. 1. Development of combine harvester selling numbers in period 2000-2016

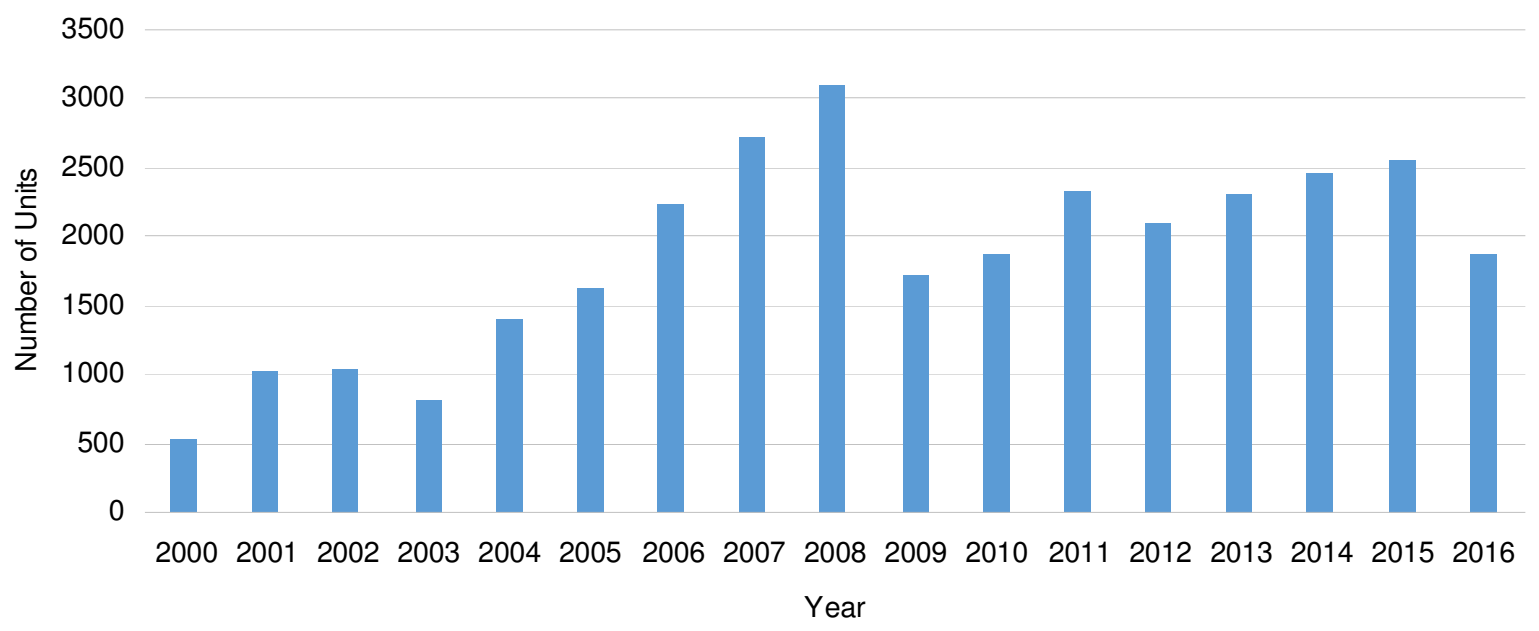

Fig. 2. Development of tractor selling numbers in period 2000-2016 
The numbers of the new tractors are shown in Fig. 3. Zetor is the leading brand in the Czech market for many years. Only in 2011 it was skipped by John Deere. The number of sold tractors is decreasing from the year 2011 until now. It is due to saturation of the market, higher efficiency and power of the new tractors. Higher durability also affects longer time of utilization of machines and prolongation of renewing time.

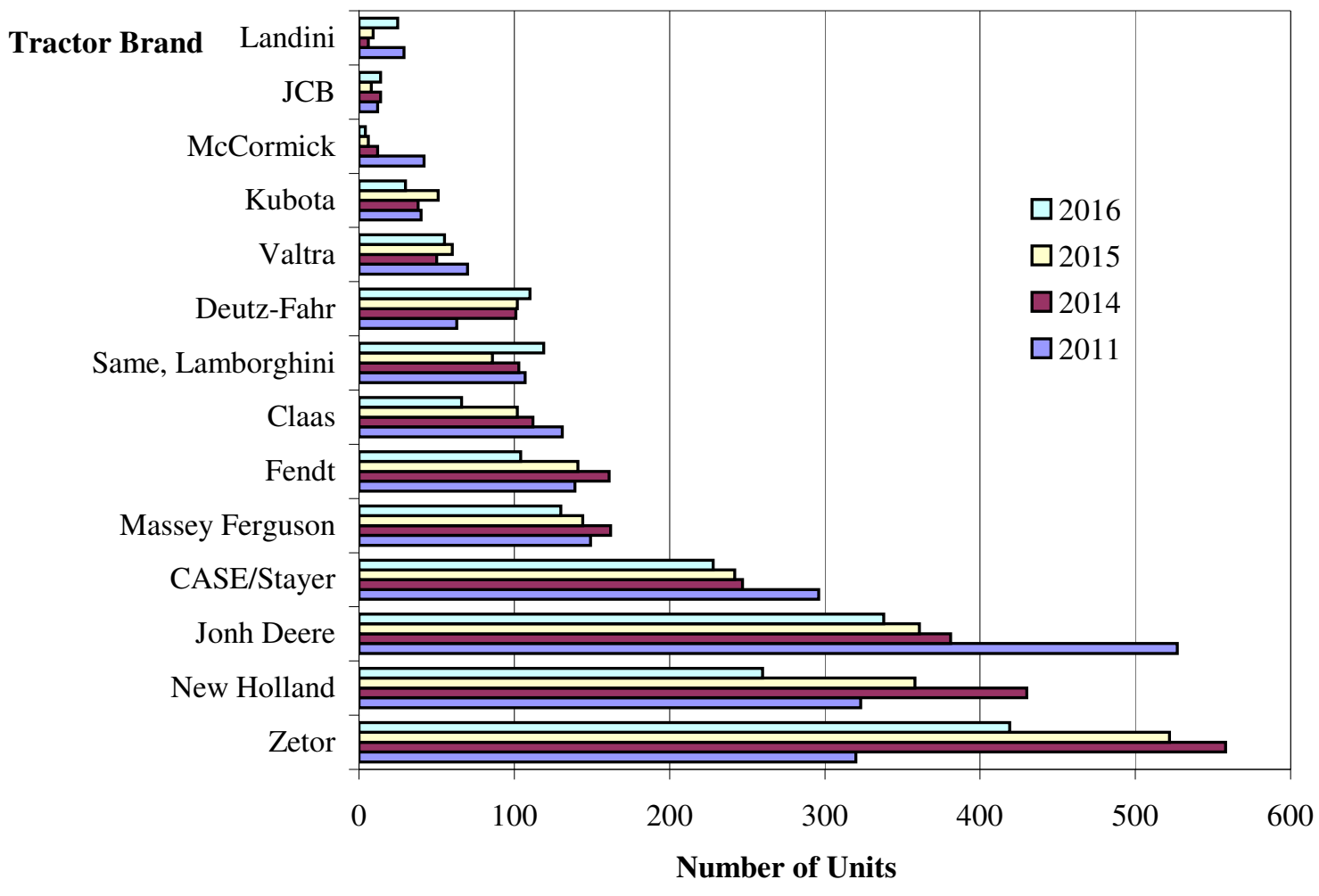

Fig. 3. Development of tractor selling numbers according to brand in 2011, 2014-2016

A few players on the market place characterize the self-propelled forage chopper sector. There are only 4 main producers of these machines. Fig. 4 gives an overview of choppers sold in the Czech Republic in selected years. The dominant position on the market is held by Claas machines, with a stable number of selling machines. The second big player is Krone with the high power model BigX. Higher number of these machines sold in recent years is especially connected with biogas production, due to the crucial role of forage choppers in raw material production for biogas power plants.

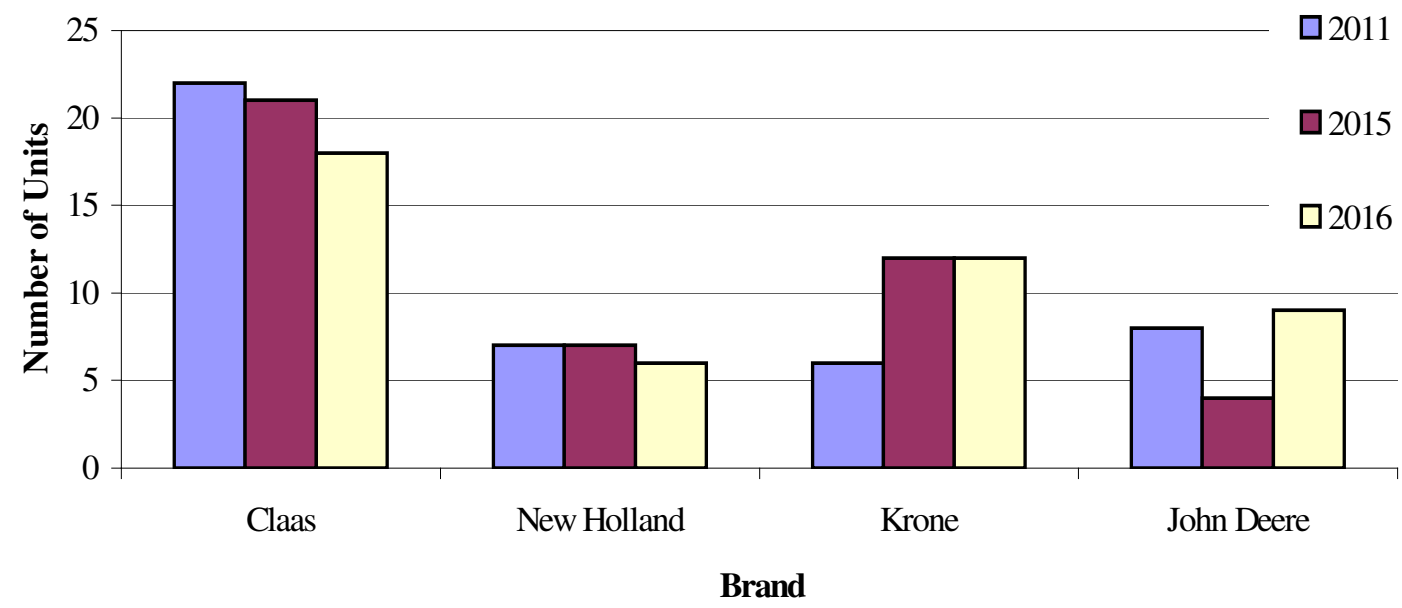

Fig. 4. Development of forage chopper selling numbers according to brand in 2011, 2015 and 2016 


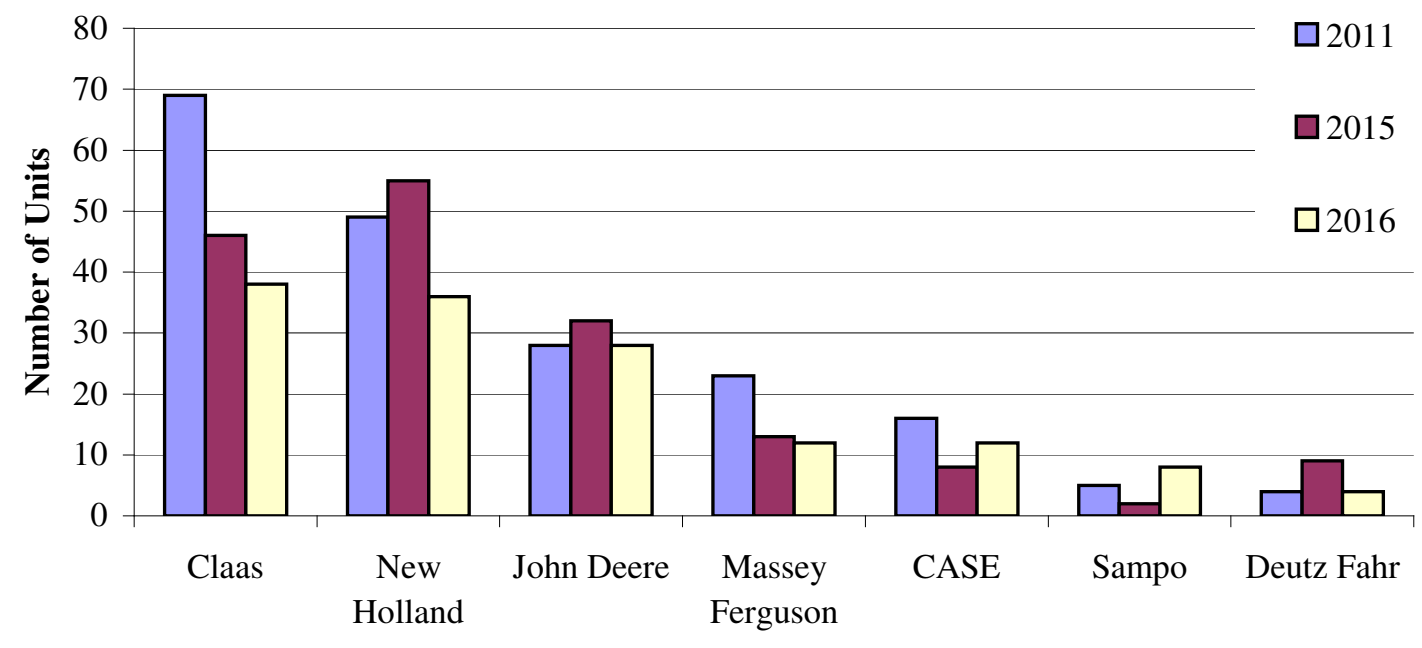

Brand

Fig. 5. Development of combine harvester selling numbers according to brand in 2011, 2015 and 2016

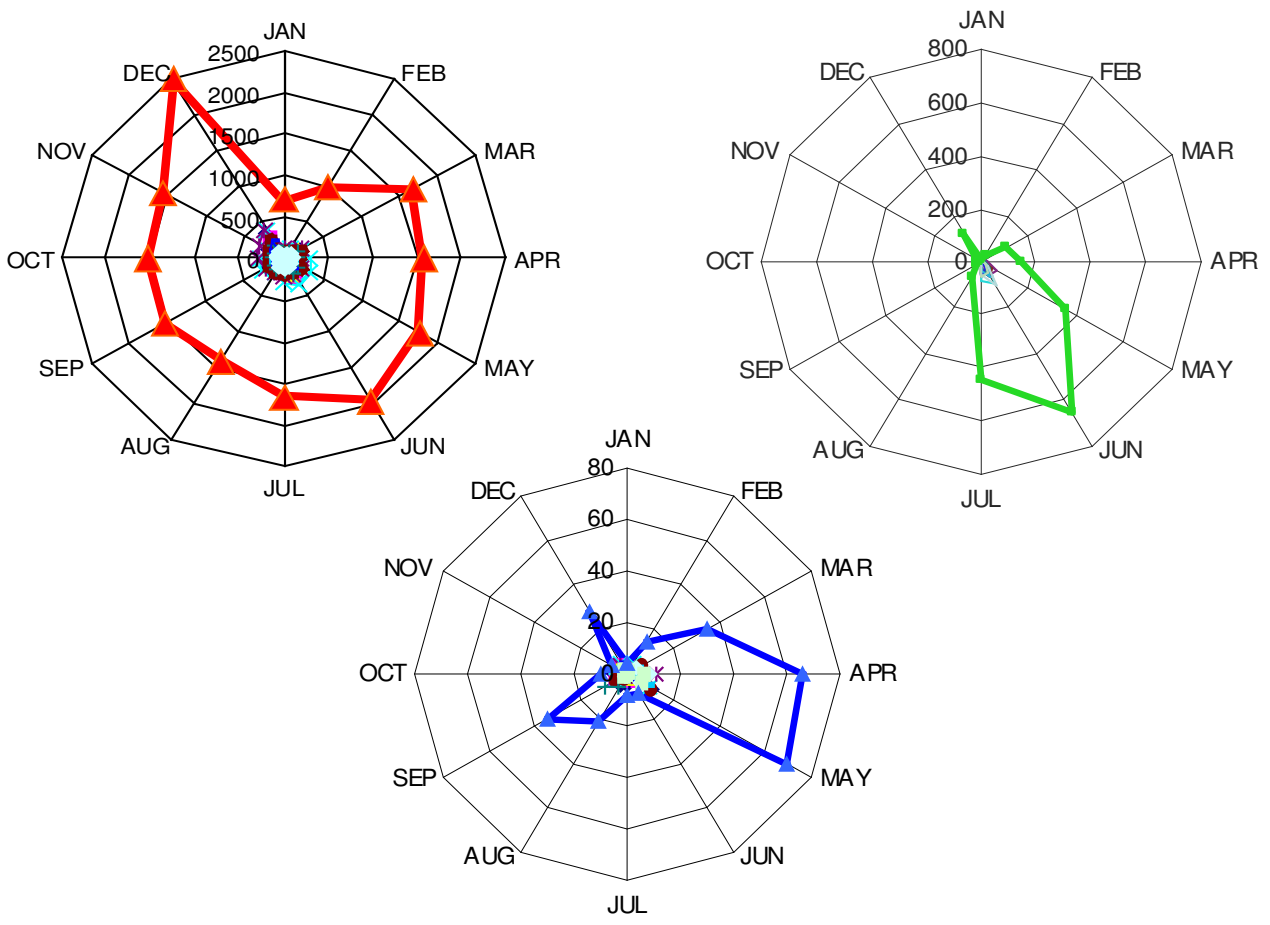

Fig. 6. Typical season peaks of selling machines - tractors (left), combine harvesters (right) and forage choppers (middle down)

Evaluation of combine harvester selling numbers is given in Fig. 5. There was big investment to these machines in the 90's, where old combine harvesters were replace by the new technology. After that, the renewing of machines is in approx. 6 year cycles. However, the total sold number was decreasing in the last 10 years (Fig. 1, Fig 5). Total number is affected by higher capacity and power of the new combine models. Compared to the past, now just one high capacity combine harvester works as 4 or 5 machines used in the 80's. The leading brand on the Czech market is Claas combines. Machines of New Holland brand are strong competitors to Claas and John Deere.

Evaluation of selling units in different month of the year is interesting (Fig. 6). There is a data set from 10 season's evaluation. Peak season for combine harvesters starts at half of April and finishes at the end of June. Forage choppers have two peaks - in spring and September in the autumn. Tractors are selling during all year with the peak in December and a low season in January. 


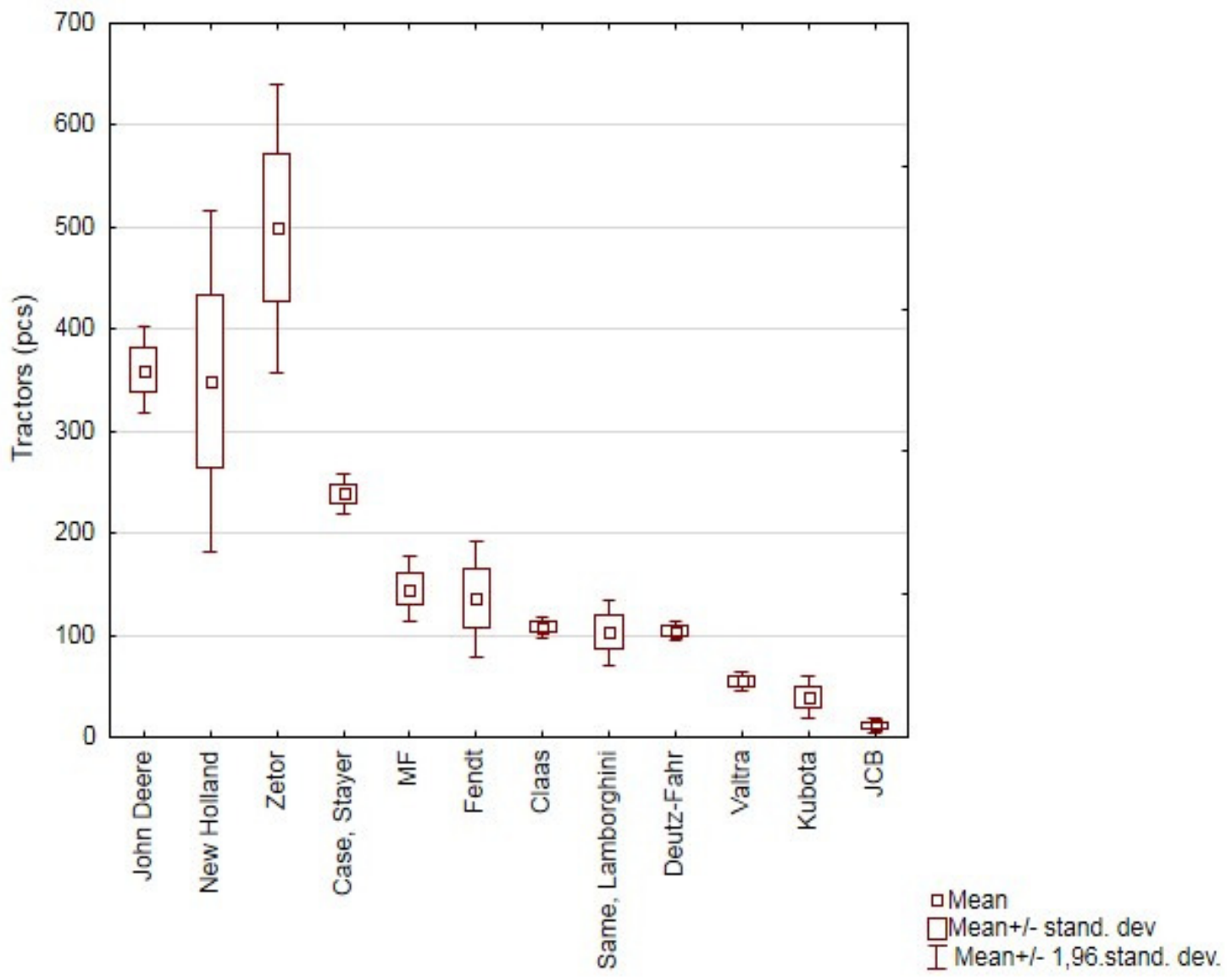

Fig. 7. Results of ANOVA evaluation of selling tractor units by brand

There two groups of brands occurred - No. 1 John Deere, New Holland, Zetor and Case and No. 2 the other brands. There is statistically significant difference on the chosen level of relevance ( $\alpha=0.05$ ) between these two groups (Fig. 7).

There is a connection with the monetary cycle, the EU and national agricultural sector subsidies schedule and innovations of new machines. The highest number of the registered tractor unit brands has ZETOR (128414 units, $75.7 \%$ of registered tractors), followed by JOHN DEERE (8937 units, $6.7 \%$ of registered tractors), NEW HOLLAND (4 015 units, $3.4 \%$ of registered tractors), CASE (3740 units, $3.2 \%$ ) and others. Almost $72 \%$ of the tractors in this database are over 10 years old.

If we compare the market share with similar countries in Europe, John Deere and New Holland occurred as the market leaders. In Table 1 the first 4 most sold brands in selected EU countries are displayed.

Table 1

Brand's turn in selected countries by number of tractor sale in 2017 [9]

\begin{tabular}{|c|c|c|c|c|}
\hline Slovenia & Poland & Hungary & Lithuania & Bulgaria \\
\hline $\begin{array}{c}\text { New Holland } \\
\text { (161) }\end{array}$ & $\begin{array}{l}\text { New Holland } \\
\text { (1290) }\end{array}$ & $\begin{array}{c}\text { John Deere } \\
\text { (594) }\end{array}$ & $\begin{array}{c}\text { John Deere } \\
\text { (313) }\end{array}$ & $\begin{array}{c}\text { John Deere } \\
(251)\end{array}$ \\
\hline $\begin{array}{c}\text { Same/Lamborghi } \\
\text { ni (124) }\end{array}$ & $\begin{array}{c}\text { John Deere } \\
\text { (1105) }\end{array}$ & $\begin{array}{c}\text { New Holland } \\
\text { (239) }\end{array}$ & $\begin{array}{c}\text { Case/Stayer } \\
\text { (235) }\end{array}$ & $\begin{array}{c}\text { New Holland } \\
\text { (138) }\end{array}$ \\
\hline $\begin{array}{c}\text { Case/Steyer } \\
\text { (121) }\end{array}$ & $\begin{array}{l}\text { Zetor } \\
(1103)\end{array}$ & $\begin{array}{c}\text { Case/Steyer } \\
\text { (204) }\end{array}$ & $\begin{array}{l}\text { Zetor } \\
(157)\end{array}$ & $\begin{array}{l}\text { Kubota } \\
(129)\end{array}$ \\
\hline $\begin{array}{c}\text { John Deere } \\
\text { (97) }\end{array}$ & $\begin{array}{l}\text { Ursus } \\
\text { (903) }\end{array}$ & $\begin{array}{l}\text { Claas } \\
(131)\end{array}$ & $\begin{array}{c}\text { New Holland } \\
\text { (127) }\end{array}$ & $\begin{array}{c}\text { Case/Steyer } \\
(103)\end{array}$ \\
\hline
\end{tabular}


According to the numbers of the sold tractors the Czech market is quiet small. One of the biggest markets in Europe is Poland (over 12000 tractors sold in 2017) and Germany (more than 32000 tractors in 2017).

\section{Conclusions}

1. Zetor tractors are the dominant machines on the Czech market in the low and middle power class tractors.

2. The total number of units sold on the Czech market is decreasing due to higher power and capacity of the new machines.

3. Renewal of combine harvesters depends on a 6 year cycle due to the depreciation period in accounting.

4. The number of selling machines is affected by the commodity process and by the level of subsidies.

5. The selling process of machines has a seasonal character, depending on the machines.

6. Jonh Deere and New Holland are the global market leaders in the tractor segment.

\section{References}

[1] Abraham Z. Analýza vybavení a obnovy techniky v zemědělství. (Analysis of Equipment and Innovation of Agricultural Technology). AgritechScience [online], 2012, Vol. 6, No. 3, pp. 1-6. ISSN 1802-8942. [online] [11.01.2018] Available at:http:www.agritech.cz/clanky2012-3-1.pdf (In Czech).

[2] Stehno L. Prodej traktorů v Evropě (Tractors selling in Europe). Mechanizace zemědělství, Vol. 58 (6), 2017, 47 p. (In Czech)

[3] Søgaard H.T., Sørensen C.G. A model for optimal selection of machinery sizes within the farm machinery system. Biosystems Engineering, vol. 89 (1), 2004, pp. 13-28.

[4] Kavka M. a kol.: Normativy pro zemědělskou a potravinářskou výrobu (Regulations for Agricultural and food production), Prague, ÚZPI, 2006, pp. 395, ISBN 80-7271-163-6. (In Czech).

[5] ČSÚ Praha: Agrocenzus 2010 - strukturální šetření v zemědělství a metody zemědělské výroby (Agrocenzus 2010 - structural evaluation of agriculture and productions processes). Prague, 2011, ISBN 978-80-250-2112-5 (In Czech)

[6] Averkieva K.V., Dan'shin A.I., Zemlyanskii D.Y., Lamanov S.V. Strategic challenges of the development of agriculture in Russia (2017) Regional Research of Russia, 7 (4), pp. 322-332.

[7] Lefebvre M., De Cuyper K., Loix E., Viaggi D., Gomez-Y-Paloma S. European Farmers Intentions to Invest in 2014-2020: Survey Results. JRC90441, JRC Working Papers, 2014. Joint Research Centre, 100 p. ISBN 978-92-79-38475-2 [online] [25.02.2018] Available at: http://publications.jrc.ec.europa.eu/repository/bitstream/JRC90441/20final.pdf

[8] Collective of authors. SDZT Annual Report. Prague, 2017, 6 p.

[9] Stehno L. Prodej traktorů v Evropě - 2017 (Tractors selling in Europe - 2017). Mechanizace zemědělství, Vol. 59 (4), 2018, 49 p. (In Czech) 